\title{
Sándor István
}

\section{A képmáshoz való jog és a sérelemdíj bírósági gyakorlatának tendenciái}

\author{
Tendencies in Judicial Practice of Right to Own Portrait \\ and of Fine for Offence
}

\begin{abstract}
Absztrakt
A személyiségi jogok védelme napjainkban kiemelt jelentőséggel bír, tekintettel a képmás és hangfelvétel rögzítésére és továbbítására alkalmas technológiai fejlődésre és a közösségi média mindennapi szerepére. Különösen érzékeny ez a kérdéskör olyan esetekben, amikor valaki nem kívánja a nyilvánosság számára megosztani a fényképét, de hivatásának gyakorlása folytán mégis erre kényszerül. Tanulmányomban a szolgálatot teljesítő személyek képmáshoz füződő jogának szabályozását és joggyakorlatát kívánom áttekinteni.
\end{abstract}

Kulcsszavak: sérelemdíj, képmáshoz való jog, bíróság, személyiségi jogok

\begin{abstract}
The protection of personal rights has an outstanding importance nowadays under consideration the development of technology for fixation and forwarding of pictures and audio recordings and the everyday role of the social media. Especially sensitive is this in cases when someone does not intend to share his portrait with the public but will be forced to do so because of his work. In this paper I intend to make a survey of the regulation and the juridical practice of rights to portrait for persons in public service.
\end{abstract}

Keywords: fine for offence, right to portrait, court, personal rights

\section{A személyiségi jogokról általában}

A felvilágosodás, a polgári korszak biztosította a személyiségi jogok védelmének elötérbe kerülését (Székely, 2011, 19.). Ennek eredménye, hogy a magyar 
magánjogi szakirodalomban a 19. század második felétől kezdve a kérdéskört számos neves jogtudósunk vizsgálja (Frank Ignácz, Fogarassy János, Wenzel Gusztáv, Zlinszky Imre, Pikler Gyula, Szladits Károly, Grosschmid Béni, Szászy-Schwarz Gusztáv, Marton Géza stb.). 1 Az 1900. évi magánjogi törvénytervezet már tartalmazott szabályozást a személyiségi jogok megsértése esetére. Ezt követik egyes külön törvények, így a sajtóról szóló 1914. évi XIV. törvénycikk, amely helyreigazítási jogokat állapított meg (20-23. §-ok), büntető rendelkezéseket tartalmazott (24-31. §-ok) és a nem vagyoni kár tekintetében a sajtó jogi felelősségét is először szabályozta Magyarországon (39. §). A kártérítés mértékének kialakítását ez a törvényünk a bíróság mérlegelési jogkörében hagyta meg. ${ }^{2}$

A becsület védelméről szóló 1914. évi XLI. törvénycikk a becsületsértés és rágalmazás büntetőjogi védelmét biztosította. Itt szeretnék utalni arra, hogy a magyar büntetőjogban létezett az úgynevezett szabadságelvonási díj, illetve az ártatlanul elítéltnek fizetendő sérelemdíj is a bünvádi perrendtartásról szóló 1896. évi XXXIII. törvénycikk 589. §-a alapján. Ezen kívül a Magánjogi törvényjavaslat (Mtj.) 1114. §-a is szabályozta a nem vagyoni kár okozásáért való felelősséget (Zoltán, 1961, 405.), vagyis a második világháború előtti magánjog gyakorlata kidolgozta az eszmei károkért való kárpótlás elveit, azonban az ezzel kapcsolatos elvi határozatok 1952-ben eltörlésre kerültek, és helyettük a III. számú Polgári Elvi Döntés 1953-ban bevezette az általános kártérítés jogintézményét (Bónis, 1980, 342.).

Az 1959. évi Polgári Törvénykönyv ${ }^{3}$ (továbbiakban Ptk.) eredetileg a személyiségi jogokat személyhez füződő jogok elnevezéssel szabályozta. Az eredeti szabályozás egy generálklauzulát tartalmazott, és nevesítve tartalmazta a név, a jóhírnév, a levéltitok, a magánlakáshoz és a jogi személy céljára szolgáló üzlethelyiséghez füződő jog, a képmás és hangfelvétel, valamint a szellemi alkotásokhoz, a szerzői, találmányi, újítói, valamint a védjegy- és mintaoltalomhoz füződő jog védelmét. ${ }^{4}$

Az 1959. évi Ptk. 1977. évi novelláris módosítása számos jelentős újítást eredményezett ezen a területen. A személyhez és a szellemi alkotásokhoz füződő jogok védelme körében a régi Ptk. továbbra sem adott taxatív felsorolást, de pontosította a korábbiakat. A képmás és a hangfelvétel védelme tekintetében föszabály szerint az érintett személy beleegyezése volt szükséges, ami alól

1 A személyiségi jogok megsértésének a tételes jogi és jogirodalmi fejlődését Magyarországon. (Görög, 2004, 3., Landi, 2014, 65.)

2 Az 1914. évi XIV. törvénycikk 39. §-ához írt indokolásának 5. pontja.

3 1959. IV. törvény a Magyar Köztársaság Polgári Törvénykönyvéről.

4 1959. IV. törvény Ptk. 81-87. §-ai. 
kivétel a nyilvános közszereplés esete. Hatóság engedélyével lehetőség nyílt arra, hogy az eltünt személy képmását nyilvánosságra hozzák, de ennek további feltétele a nyomós közérdek vagy méltánylást érdemlő magánérdek. A súlyos büncselekmény miatt büntetőeljárás alá vont személy képmását (hangfelvételét) nyomós közérdekből, az illetékes hatóság engedélyével szintén nyilvánosságra lehet hozni.

Napjainkban a személyiségi jogok védelme több szinten is megvalósul a magyar jogrendszerben. Az Alaptörvény és az egyes nemzetközi egyezmények közjogi védelemben részesítik azokat ${ }^{5}$, továbbá a büntetőjog is számos tényállást nevesít. ${ }^{6}$ Ehhez képest a polgári jog általános védelmet teremt a személyiségi jogoknak, amelyek megsértéséhez pedig magánjogi jogkövetkezményeket, szankciókat rendel.

A Ptk. általánosan védelemben részesíti a személyiségi jogokat és előírja, hogy azokat mindenki köteles tiszteletben tartani. Ez alapján a védelem mindennemű személyiségi jogra kiterjed. A Ptk. tartalmaz egyes konkrét tényállásokat, azonban ez nem jelenti azt, hogy csak ezekre szükítené le a lehetséges személyiségi jogok körét.

A személyiségi jogok megsértése azt eredményezi, hogy a sértő személy köteles bizonyítani a jogellenesség hiányát. Így a személyiségi jogokat nem sérti az a magatartás, amelyhez a jogosult hozzájárult. A személyiségi jogokat egyébként korlátozó szerződés vagy egyoldalú nyilatkozat semmis. ${ }^{7}$

A személyiségi jogok célja más személyek személyiségi jogainak és érdekeinek tiszteletben tartása. A személyiségi jogok az emberi méltóságból fakadnak, a személyiségi jogok védelme az emberi méltóság elismerését fejezi ki. Szorosan ehhez kapcsolódik a személyiség társadalmi életben való elismerésének, tiszteletének követelménye. Másrészről a személynek joga van ahhoz, hogy személyiségét szabadon érvényesíthesse és abban senki se gátolja. Ennek korlátját csak mások jogainak sérelme képezi. ${ }^{8}$

Jól mutatja a személyiségi jogok általános védelmének követelményét az Alkotmánybíróság ítélkezési gyakorlata: ,Az Alkotmánybiróság az emberi méltósághoz való jogot az ún. általános személyiségi jog egyik megfogalmazásának tekinti. A modern alkotmányok, illetve alkotmánybirósági gyakorlat az általános személyiségi jogot különféle aspektusaival nevezik meg: pl. a személyiség

5 Magyarország Alaptörvénye, Szabadság és felelősség, különösen a II. és az V-IX. cikkek továbbá az Európai Egyezmény az emberi jogokról, a Polgári és Politikai jogok Nemzetközi Egyezségokmánya (amit az ENSZ 1966. december 16-án fogadott el és Magyarországon az 1976. évi 8. tvr. hirdetett ki.

6 Btk. XXI. fejezete, különös tekintettel a 226/A. és 226/B. §-okra.

7 Szakirodalom a személyiségi jogokhoz: Petrik, 2001; Görög, 2010; Boytha, 2008; Szabó, 2008; Tattay. 2008, 2006.

8 BDT 2009/2126. 
szabad kibontakoztatásához való jogként, az önrendelkezés szabadságához való jogként, általános cselekvési szabadságként, avagy a magánszférához való jogként. Az általános személyiségi jog anyajog, azaz olyan szubszidiárius alapjog, amelyet mind az Alkotmánybiróság, mind a biróságok minden esetben felhívhatnak az egyén autonómiájának védelmére, ha az adott tényállásra a konkrét, nevesitett alapjogok egyike sem alkalmazható". ${ }^{9}$

\section{A képmáshoz való jog hatályos polgári jogi szabályozása}

A Ptk. generálklauzulája a személyiségi jog általános védelmét írja elő. Ehhez képest a Ptk. egyes részletszabályokat is megállapít, így nevesített személyiségi jog a képmáshoz és a hangfelvételhez való jog. A generálklauzula alapján azonban a társadalmi, gazdasági változásoknak megfelelően a Ptk. katalógusában külön nem nevesített személyiségi jogok védelmére is sor kerülhet. ${ }^{10}$

A személyiségi jogok a jogi személyeket is megilletik, amennyiben a jog jellege ezt nem zárja ki. Ebből eredően csak a magánszemélyek jogosultak védelemre nem, faj, nemzetiség, felekezet szerinti megkülönböztetés, a lelkiismereti szabadság megsértése, a személyes szabadság korlátozása esetén, a testi épség, egészség, becsület és emberi méltóság sérelme miatt. A személyiségi jogok védelme mindenkivel szemben érvényesíthető, mindenki köteles azokat tiszteletben tartani. A személyiségi jogokat nem lehet korlátozni és kizárni ${ }^{11}$, az arról történő lemondásnak kifejezettnek kell lennie, és nem lehet kiterjesztően értelmezni ${ }^{12}$. A Ptk. a közéleti szereplők esetében előírást tartalmaz a személyiségi jogok védelmének korlátozására nézve. Ez alapján a közügyek szabad vitatását biztosító alapjogok gyakorlása a közéleti szereplő személyiségi jogainak védelmét méltányolható közérdekböl, szükséges és arányos mértékben, az emberi méltóság sérelme nélkül korlátozhatja. A személyiségi jogok megsértése az állam, az állami szervek hatósági eljárásában is megtörténhet, ilyen esetben is a polgári jogi szabályokat kell alkalmazni. ${ }^{13}$ Ugyancsak nem zárja ki a személyiség védelmét, ha az állítólagos jogsértést egyházi szervezet tagja, az egyházi tevékenységével összefüggésben követi el. ${ }^{14}$ A személyiségi jogok

9 8/1990. (IV. 23.) AB határozat.

10 Például a házasságkötést megörökítő pótolhatatlan felvételek végleges elvesztése alkalmas a személyiségi jogok megsértésére. BDT 2008/1899.

11 BH 1992/455., BH 2002/7.

12 Például egy sportoló esetében, ha a sérülést a játékszabályokat durván sértő károkozó magatartással okozzák, úgy az az előzetesen vállalt kockázat határain kívül esik. BDT 2004/932.

13 BH 2002/178., BH 1997/276.

14 BH 2004/180. 
abszolút szerkezetű jogviszonyt hoznak létre, mindenkivel szemben kikényszeríthető az érvényesülésük. A személyiségi jogok védelme szempontjából nem lehet különbséget tenni a jogsértő személy vonatkozásában, például akár az Országgyülés felelössége is megállapításra kerülhet. ${ }^{15}$

Képmás vagy hangfelvétel elkészítéséhez és felhasználásához az érintett személy hozzájárulása szükséges. A hozzájárulásnak kifejezettnek és határozottnak kell lennie ${ }^{16}$, azt kiterjesztően nem lehet értelmezni ${ }^{17}$. A hangfelvétel engedély nélküli készítése már önmagában jogsértést képez. ${ }^{18}$ Nincs jelentősége annak, hogy a képmás vagy a hangfelvétel rögzítése milyen eszközzel történt, és annak sem, hogy a jogsértö a készített képmás vagy hangfelvétel rögzítését felhasználja-e, nyilvánosságra hozza-e. A jogsértőt terheli a bizonyítási kötelezettség arra vonatkozóan, hogy a rögzítés elkészítése nem volt visszaélésszerü. ${ }^{19}$ Ilyen eset lehet az, ha a rögzítő eszközben rejlö véletlen hiba vagy hibás kezelés folytán kerül sor a rögzítésre.

A rögzítésre adott engedély nem terjed ki a nyilvánosságra hozatalra, a felhasználásra, illetve az egyszeri felhasználási engedély nem jelent további használatra is engedélyt. Az újbóli felhasználáshoz adandó engedély be nem szerzése tekintetében az sem mentesíti a felhasználót, hogy az idő múlása miatt a jogosult személy felkutatása csak jelentős nehézségek árán lett volna lehetséges. ${ }^{20}$ Egy korábban adott hozzájárulás alapján felhasznált fénykép újbóli hozzájárulás nélküli felhasználása önmagában is jogsértést valósít meg. ${ }^{21}$

Nincs szükség hozzájárulásra a felvétel elkészítéséhez és az elkészített felvétel felhasználásához tömegfelvétel és nyilvános közéleti szereplésről készített felvétel esetén. A felvétel készítésére és nyilvánosságra hozatalára adott engedélynek kell tekinteni, ha az érintett személy nyilvános közszereplésen vesz részt. Önmagában a nyilvános helyen tartózkodás esetén csak az egyediesítés igénye nélkül készített felvételhez nem szükséges az érintett személy hozzájárulása. Nem egyediesített a felvétel, ha a személyt a tömeg részeként mutatja be. Nyilvános közszereplésen részt vevő személynek számolnia kell azzal, hogy képmását, hangfelvételét megörökítik. A rendörségi fogdában történő megjelenés például nem számít nyilvános közszereplésnek. ${ }^{22}$ Hasonlóképpen, a bírósági tárgyalás sem minősül olyan nyilvános eseménynek, amelyről az elkészült

\footnotetext{
15 BH 1997/6.

16 BDT 2007/1682.

17 BH 2002/7.

18 BH 2008/266

19 BH 2008/266.

20 BDT 2009/1962.

21 BH 1995/632.

22 BDT 2007/1663.
} 
tudósítás illusztrációjaként a fényképfelvétel készítéséhez a tárgyaláson résztvevő jogi képviselő hozzájárulására ne lenne szükség. ${ }^{23}$

A képmás nyilvánosságra hozatalának tilalma nem vonatkozik a nyilvános eseményekről, rendezvényekről, táj- és utcarészletekről készült felvételekre, amikor tehát az ábrázolás módja nem egyéni, a felvétel összhatásában örökíti meg a nyilvánosság előtt lezajlott eseményeket. A nyilvánosságra hozatalhoz a felvételen ábrázolt személy hozzájárulására viszont szükség van, ha - az eset összes körülményeire tekintettel - megállapítható a felvétel egyedisége, egyéni képmás jellege. ${ }^{24}$ Amennyiben nyilvános eseményekről, rendezvényekről készítenek felvételt, és az ábrázolás nem egyéni, akkor nem eredményez jogsértést. Ugyanakkor, ha a felvételen szereplő személy egyéni képmása megállapítható, akkor csak az ő hozzájárulásával hozható nyilvánosságra. ${ }^{25}$

Önmagában egy hangfelvétel létezéséről a tartalmának szóbeli ismertetésével, illetve a hangfelvétel leírt anyagának közzétételével a közvélemény tájékoztatása csak tényközlés, ezzel a hangfelvétel nyilvánosságra hozatala nem történik meg, azaz személyiségi jogot nem sért. ${ }^{26}$

Amennyiben valaki hamis, valótlan tényállítást kíván leleplezni a hangfelvétellel, úgy nem lehet jogsértésre hivatkozni. ${ }^{27}$ Szintén igaz ez a birtokháborításról készült videofelvétel esetén is. ${ }^{28}$ Viszont a szomszédos lakóépületben folytatott tevékenység engedély nélküli filmre vétele jogsértés bizonyítása érdekében birtokháborítást valósíthat meg, még ha személyiségi jogot nem is sért. ${ }^{29} \mathrm{~A}$ rejtett kamerával készített videofelvétel büntetőeljárásban bizonyítékként vehető figyelembe, viszont csak polgári perben dönthető el az, hogy személyiségi jogot sért-e. ${ }^{30}$ Közterületen elhelyezett térfigyelö kamerák esetén az azokkal készített felvétel csak bünmegelőzési célokat szolgálhat. A magánterületen elhelyezett térfigyelő kamerával a közterületet és mások magánterületét tilos megfigyelni. A fényképfelvételhez történő hozzájárulás nem jelenti egyúttal a fénykép felhasználáshoz való hozzájárulás megadását is ${ }^{31}$, illetve a korábban adott felhasználáshoz adott hozzájárulás a fénykép újbóli, de újabb engedély nélküli hozzájárulásának nem tekinthető, és jogsértést valósít meg. ${ }^{32} \mathrm{~A}$ képés a hangfelvétel szétválasztása (play back) is aggályosnak tekintendő jogi

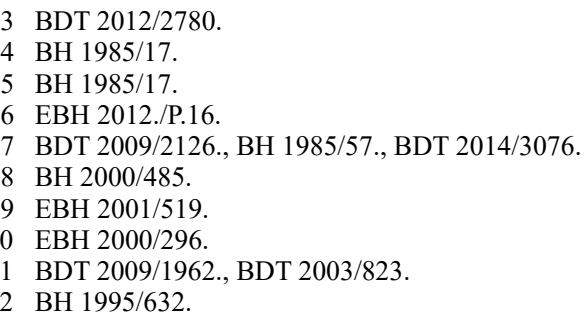


szempontból. Szinkronizálás esetén a más színész hangjának az eredeti színész képmásához történő társításához külön engedély nem szükséges, csak ha ezt eredetileg kikötötték. ${ }^{33}$

\section{A szolgálati kötelezettséget teljesítők sajátos jogi helyzete}

A szolgálatot teljesítő személyek esetében érthető a magas fokú igény arra, hogy tevékenységük társadalmilag is ellenőrizhető legyen, a jogszerü fellépésük és eljárásuk a közvélemény számára megnyugtató módon bizonyíthatóvá váljon. Méltányolható közérdek az, hogy a kényes helyzetben (tüntetés, sportesemény stb.) intézkedő, szolgálatot teljesítő személyek beazonosíthatók legyenek. Másrészről viszont a szolgálat teljesítése során meghozott döntések általában nem az adott személy saját akaratelhatározásán, hanem sokkal inkább a parancsok végrehajtásán alapulnak. Esetleges felelösségre vonás érdekében nem szükséges az adott személy képmásának nyilvánosságra hozatala, arra enélkül is lehetőség van (Pap, 2017, 119.; Fejes, 2017, 148.). A szolgálatot teljesítő személy és egyben családjának védelmét eredményezi az, ha a képmását nem lehet szabadon nyilvánosságra hozni. Ebben a körben az első fontos kérdés a közszereplés megítélése. Közéleti szereplőnek az minősül, aki a közügyek szabad vitatását biztosító alapjogát gyakorolja.

A régi Ptk. 80. § (2) bekezdése a közszereplés fogalmát használta: „Képmás vagy hangfelvétel nyilvánosságra hozatalához - a nyilvános közszereplés kivételével - az érintett személy hozzájárulása szükséges." Ezt a hatályos Ptk. közéleti szereplő terminológiára változtatta. A Ptk. 2018. évi módosítása kiegészítette a korábbi normaszöveget, amely alapján a közéleti szereplő személyiségi jogainak védelme szükséges, és arányos mértékben, az emberi méltóság sérelme nélkül korlátozható, azonban ez nem járhat a magán- és családi életének, valamint otthonának sérelmével. A közéleti szereplöt a közügyek szabad vitatásának körén kívül eső közléssel vagy magatartással szemben a nem közéleti szereplővel azonos védelem illeti meg. Ez azt jelenti, hogy a közéleti szereplő nagyobb mértékben köteles türni a személyiségi jogait érintő bírálatot, de a magánélete során teljes mértékben azonos elbírálás alá esik a nem közszereplőkkel.

Nyilvános közszereplésnek minősül például az a tájékoztatás, amit a rendőrségi vezető ad a sajtó munkatársának a rendőrség munkájával kapcsolatban. ${ }^{34}$ A közszereplés azonban csak ésszerü keretek között vehetö figyelembe, így a

33 BH 1976/492.

34 BDT 2006/1298. 
közszereplő képmása csak a közszerepléseivel összefüggésben használható fel. ${ }^{35}$ A fentiekből eredően komoly dilemmát jelent a nyilvános helyen vagy közterületen szolgálati kötelezettséget teljesítő vagy munkát végző személy jogi helyzetének megítélése. A jelenlegi joggyakorlat szerint, ha valamely jelenkori eseménnyel kapcsolatban a nyilvánosság figyelme elé került személyről képmás készül, úgy az az engedélye nélkül nyilvánosságra hozható. Ez azonban egy jelentős szempontváltás eredményeként alakult ki.

A korábbi bírósági gyakorlat szerint a nyilvános helyen munkáját végző személy a közszereplés szándékának hiányában nem volt közszereplőnek tekinthető (Kárpáti-Kóczián, 2014, 72.). Az első komoly áttörést 2011-ben a Pécsi Ítélőtábla döntése jelentette, amelyben egy labdarúgó-mérkőzést biztosító rendőr arcképpel együtt történő ábrázolását nem minősítette személyiség jog megsértésének. Az ítélet indokolása szerint „,... a tömegrendezvényen való rendöri részvétel, az ilyen rendezvényeken való rendöri rendfenntartás, a sport-vagy politikai rendezvényeken a szurkolótáborok egymás elleni fellépésének megakadályozására kivezényelt rendörök tevékenysége - különösen a 2006. öszi budapesti események fényében - nyilvános közszereplésnek minösül. "36 A Kúria annak tükrében, hogy az ellentétes bírósági gyakorlat megszüntetésre kerüljön, jogegységi határozatot hozott, amelyben leszögezte, hogy a nyilvános helyen vagy közterületen szolgálati kötelezettséget teljesítő vagy munkát végző személy e tevékenységének ellátása során nem minősül közszereplőnek. Ebből eredően a személyt beazonosítható módon, egyediesítetten ábrázoló képmás vagy hangfelvétel nyilvánosságra hozatalához szükséges a hozzájárulása. ${ }^{37}$

Az Alkotmánybíróság is foglalkozott ezzel a kérdéskörrel és a Kúria álláspontját nem osztotta. Az Alkotmánybíróság döntésének indokolása szerint: ,, ... rendöri bevetés demonstrációkon minden esetben a jelenkor eseményének minösül, még akkor is, ha a rendörök nem igazi résztvevöi a történésnek. Ezért az arról készült felvétel a képen lévők hozzájárulása nélkül közvetithető a nyilvánosság felé, kivéve, ha ez a rendör emberi méltóságának - mint az emberi mivolt bensö lényegét feltétlenül megilletö védelemnek - sérelmét jelenti. Ilyen lehet például a hivatása gyakorlása során megsérült rendőr szenvedésének bemutatása. Eszerint a közhatalmat gyakorló személyek (és a közszereplö politikusok) esetében a személyiségvédelem korlátozottsága mindenki máshoz képest szélesebb körben minösül indokoltnak a szólás- és sajtószabadság érdekében. " ${ }^{8}$ Vagyis „, A nyilvános helyen készült, nem sértö, az érintett személyt tárgyilagosan

35 BH 2006/282.

36 BDT 2012/2609.

37 1/2012. számú BKMPJE határozat.

38 A 28/2014. (IX. 29.) AB határozat 44. és 36. pontja. 
ábrázoló felvétel általában nyilvánosságra hozható engedély nélkül, ha az körérdeklödésre számot tartó tudósitáshoz kapcsolódik, a jelenkor eseményeiröl való szabad tájékoztatáshoz kötödik. "39

Az új Ptk. hatálybalépését követően a Kúria 2015-ben hatályon kívül helyezte a korábbi jogegységi határozatát, és az Alkotmánybíróság döntésével bizonyos fokig összhangban alakította a bírósági gyakorlatot. (Koltay, 2015, 355.). Továbbra is fenntartotta azt, hogy a szolgálatot teljesítő rendőr nem minősül közszereplőnek. Ugyanakkor , ,... amennyiben a közhatalmat gyakorló személy fellépésére a közéletet befolyásoló események során kerül sor, úgy a képmáshoz való személyiségi jogainak gyakorlása, azok korlátozhatósága az általános, azaz a közéleti eseményeken pusztán jelenlévö magánszemélyek jogvédelmének szabályaihoz képest eltérö megitélés alá eshet. " ${ }^{40}$ Ennek oka elsősorban az volt, hogy a közéletet befolyásoló és közérdeklődésre számot tartó események olyan többletelemnek minősíthetök, amelyek konkrét esetben indokolhatják a közhatalmat gyakorló személy kép- és hangfelvételhez füződő személyiségi jogainak korlátozhatóságát. ${ }^{41}$

2017-ben az Alkotmánybíróság ismételten foglalkozott az üggyel, és hangsúlyozta, hogy , ,.. a jelenkori események bemutatásához füzödő alkotmányos érdek primátusát kötelesek érvényesiteni. ” Ennek megfelelően ,, ... alaptörvény-ellenesnek találta azt a megszoritó értelmezést, amely szerint kizárólag akkor volna lehetséges a felvétel készitése és közzététele, ha valamely rendöri intézkedésre vonatkozó eljárási szabályok nyilvánvaló megszegését dokumentálnák", továbbá csak akkor jogellenes a sajtószerv tudósítása, ha a tudósítás egészének tisztességessége és jóhiszemüsége nem áll fenn. ${ }^{42}$

A jelenlegi bírósági gyakorlat alapján tehát a jelenkor eseményeinek tisztességes és jóhiszemü tudósításával jogszerüen együtt járhat a szolgálatot ellátó személyek képmásának rögzítése és nyilvánosságra hozatala, de ez természetesen nem lehet hamis, öncélú vagy más módon az adott személy személyiségi jogait sértö.

\section{A személyiségi jogok megsértésének jogkövetkezményei}

A személyiségi jogok megsértése esetén sérelmet szenvedett fél bírósági úton kaphat jogvédelmet. A szankció lehet objektív, ami a jogsértő felróhatóságától

39 A 16/2016. (X. 20.) AB határozat 24. pontja és IV/2950-14/2015. számú AB határozat.

40 Az 1/2015. számú BKMPJE határozat IV.3. pontja.

41 Az 1/2015. számú BKMPJE határozat II. pontja.

42 3/2017. (II. 21) AB határozat III. 25. és 26. pontjai. 
független, és szubjektív, ami kimentési lehetőséget biztosít a jogsértő számára annak bizonyításával, hogy úgy járt el, ahogy az adott helyzetben általában elvárható. A sértett diszkrecionális joga eldönteni azt, hogy az egyes jogkövetkezmények közül melyiket kívánja alkalmazni, de lehetősége van akár az öszszes érvényesítésére is.

Akit személyiségi jogában megsértenek - az eset körülményeihez képest - polgári jogi igényeket támaszthat az elévülési időn belül. Ez irányulhat a jogsértés megtörténtének bírósági megállapítására, jogsértés abbahagyására kötelezésre és a jogsértő eltiltására a további jogsértéstő $1^{43}$, a jogsértő kötelezésére megfelelő elégtétel adására, és ennek saját költségén megfelelő nyilvánosság biztosítására, kötelezésre a sérelmes helyzet megszüntetésére, a jogsértést megelőző állapot helyreállítására, továbbá a jogsértéssel előállott dolog megsemmisítésére, illetőleg jogsértő mivoltától megfosztására, továbbá kötelezésre arra, hogy a jogsértő vagy jogutódja a jogsértéssel elért vagyoni előnyt engedje át javára a jogalap nélküli gazdagodás szabályai szerint (objektív szankciók). A személyiségi jogok megsértésének szubjektív szankciója a sérelemdíj és kártérítés. A továbbiakban a sérelemdíjról szeretnénk néhány gondolatot megosztani.

Az 1959. évi Ptk. eredetileg nem szabályozta a nem vagyoni kár intézményét. A kodifikáció során - többek között - például Beck Salamon kifejezetten bírálta ennek elhagyását (Sándor, 2018, 61.). A Legfelsőbb Bíróság III. számú Polgári Elvi Döntése szerint csak kimutatható vagyoni károkért járt kártérítés, mivel a szocialista életviszonyok között „az erkölcsi értékek nem válthatók pénzre” (Zoltán, 1961, 405.).

Az áttörésre az 1970-es évek végéig kellett várni. Eörsi Gyula már 1972-ben szorgalmazta a nem vagyoni kártérítés bevezetését (Eörsi, 1972, 73.). Törő Károly a személyhez füződő jogok esetében a védett kör tartalmi szabályozásának hiányosságaira hívta fel a figyelmet (Törő, 1972, 550.). Hozzá hasonlóan, Világhy Miklós is javasolta a nem vagyoni károk valamilyen szintü megtérítése érdekében a megfelelő jogszabályi háttér megalkotását (Világhy, 1968, 472.).

Az 1977. évi IV. törvényhez köthető a nem vagyoni kár szabályainak beépítése a régi Ptk.-ba, amelynek bevezetése elsősorban a bírói gyakorlat visszajelzése alapján vált indokolttá (Baranyai, 1978, 524.). A régi Ptk. 354. §-ába került szabályozás szük körben biztosította a nem vagyoni kártérítés iránti igény érvényesítésének lehetőségét. Ennek oka, hogy a régi Ptk. szabálya alapján a nem vagyoni kár megtérítésére csak súlyosabb esetekben kerülhetett sor, ha a károkozás a károsultnak a társadalmi életben való részvételét, illetőleg életét tartósan vagy véglegesen megnehezítette. Az Alkotmánybíróság 1992-ben

43 BH 2008/181. 
ezeket a feltételeket megsemmisítette, így a nem vagyoni kártérítés szélesebb körben alkalmazhatóvá vált (Petrik, 2013, 164.).

A hatályos Ptk. alapján, akit személyiségi jogában megsértenek, sérelemdíjat követelhet az öt ért nem vagyoni sérelemért. ${ }^{44} \mathrm{~A}$ sérelemdíj fizetésére kötelezés feltételeire - különösen a sérelemdíjra köteles személy meghatározására és a kimentés módjára - a kártérítési felelősség szabályait kell alkalmazni, azzal, hogy a sérelemdíjra való jogosultsághoz a jogsértés tényén kívül további hátrány bekövetkeztének bizonyítása nem szükséges. A sérelemdíj mértékét a bíróság az eset körülményeire - különösen a jogsértés súlyára, ismétlődő jellegére, a felróhatóság mértékére, a jogsértésnek a sértettre és környezetére gyakorolt hatására - tekintettel egy összegben határozza meg.

Lenkovics Barnabás által feltett kérdés idézése helyénvalónak tünik a sérelemdíj kapcsán is: „Van-e az új Ptk.-nak ember és társadalomképe?” A 2013. évi Ptk.-ban a 2:52. §-ban bevezetett sérelemdíj szabályai is egyfajta válasznak tekinthetők (Lenkovics, 2009, 203.). A 2013. évi Ptk. szabályának kialakítása során a jogalkotó előtt az a cél lebegett, hogy „... feloldja a nem vagyoni kártéritésben rejlö fogalmi ellentmondást, és egyben meg kivánja szüntetni a bírói gyakorlat bizonytalanságait is" (Székely, 2008, 174.). A bíróságok ugyanis eltérő gyakorlatot folytattak a nem vagyoni kártérítés megítélése során a külvilág számára felismerhető hátrány bizonyítása tekintetében (Székely, 2014, 172.).

Mindenekelőtt fontos kiemelni, hogy a jogalkotó a sérelemdíjra való igény szabályait a Ptk.-nak Az ember, mint jogalany címü Második Könyvében helyezte el, eltérően a régi Ptk. rendszertani megoldásától. A sérelemdíj tehát kikerült a kártérítési jog szabályai közül, és egyértelmúen a személyiségi jogok megsértésének szankciójaként kezelendő. ${ }^{45}$

A szabályozás alapján sérelemdíjra jogosultság feltétele a személyiségi jog megsértése folytán bekövetkező nem vagyoni sérelem. A sérelemdíjra részben a kártérítési felelősség szabályai is irányadók, így a kötelezett személye és a kimentés módja tekintetében is. Ugyanakkor jelentős újdonság a szabályozásban, hogy a jogsértés tényén kívül további hátrány bekövetkeztének bizonyítása nem szükséges. Ebből eredően a sérelemdíj mértékét a bíróság az eset körülményeire tekintettel határozhatja meg. Az egy összegben megállapítandó sérelemdíj mértékének kialakítása során a bíróság különböző szempontokat vesz figyelembe, így különös tekintettel mérlegeli a jogsértés súlyát, annak ismétlödő jellegét, a felróhatóság mértékét, a jogsértésnek a sértettre és környezetére

44 Szakirodalom a sérelemdíj témaköréhez: Szalma, 2018; Sipka-Zaccaria, 2013; Barzó-Sápi, 2016; Barzó, 2017; Pribula, 2016; Pataki, 2017; Fézer, 2008, 2011; Székely, 2011; Görög, 2004; Landi, 2014.

45 Magyarország Kormánya T/7971. számú törvényjavaslat a Polgári Törvénykönyvröl (miniszteri indokolás). 390. (Nagy, 2014; Boytha, 2003; Petrik, 2003; Szalma, 2018) 
gyakorolt hatását. Kétségtelenül igaz Görög Márta megállapítása, miszerint „,.. a bagatell személyiségi jogi sérelmek esetén a birósági mérlegelés során a méltányosság szerepe jelentösen felértékelödik." (Görög, 2014., 167.)

A sérelemdíj nem objektív személyiségvédelmi eszköz, mivel a törvény alapján lehetőség van exkulpációra. A nem vagyoni kártérítéshez képest a legjelentősebb változás abban fedezhető fel, hogy a kisebb jelentőségű személyiségi jogsértések sem utasíthatók el a bíróság által, vagyis a jogalap szempontjából ezeket is figyelembe kell venni. A sérelemdíj mértékének meghatározása során a jogalkalmazó látókörébe kerülhetnek egyéb, az előzőekben vázolt szempontok (Fézer, 2014, 339.).

Míg a vagyoni kártérítés funkciója az, hogy a károkozásból eredő, vagyonban bekövetkezett csökkenést helyreállítsa, addig a személyiségi jogok megsértése esetén a sérelmet szenvedett személy részére történő elégtétel és pénzbeli jóvátétel a cél. Ebből eredően a személyiségi jogok megsértése esetére pusztán a kártérítési felelősség szabályainak alkalmazása nem vezet kellő eredményre (Szalma, 2018, 256.).

A joggyakorlat és a szakirodalom számára is érdekes kérdéskört vet fel a csekély jelentőségü igények érvényesítésének lehetősége. A Ptk. ugyan kifejezetten nem tartalmaz de minimis szabályt, ami alapján akár arra a következtetésre is juthatnánk, hogy a sérelemdíj célja továbbra is mindennemü hátrány kompenzálása, függetlenül annak mértékétől (Vékás, 2005, 198.). A joggyakorlatban azonban továbbra is az a megközelítés látszik uralkodóvá válni, amely szerint a kisebb jelentőségű személyiség jogsértések esetére nem jár sérelemdíj.

A Fővárosi Ítélőtábla Polgári Kollégiumának véleménye már 2013-ban azt az irányt vetítette elő, hogy az érzelmi érdeksérelem esetében a sérelemdíj iránti igény nem érvényesíthető. ${ }^{46} \mathrm{~A}$ Kúria tanácsadó testülete ezzel kapcsolatban kiadott véleményében a korábbi joggyakorlat fenntartása mellett érvelt, amikor a kis összegü sérelemdíj megfizetésére irányuló kereseti kérelem elutasítására tett javaslatot. ${ }^{47}$

\section{Befejezés}

Kétségtelen, hogy a bírósági joggyakorlat számára jelentős kihívásnak tekinthető a sérelemdíj megítélése során a bagatell ügyek kiszürése (Fuglinszky, 2015,

\footnotetext{
46 A Fővárosi Ítélőtábla Polgári Kollégiuma 1/2013. (VI. 17.) számú határozatával elfogadott kollégiumi véleménye a nem vagyoni kártérítés/sérelemdíj megtérítése iránti követelések elbírálásának a polgári perben felmerülő egyes kérdéseiröl 5. pontja.

47 2013. évi Ptk. Tanácsadó Testület véleményei, Ptk. 2:52. §.
} 
840.). Mint Lábady Tamás rámutatott, a Ptk. hatályba lépését követően az elsőfokú bíróságok kétféle gyakorlatot alakítottak ki. Az egyik jogértelmezés alapján a bagatell ügyekben is megítélték a sérelemdíjat, természetesen csekély összegben. A másik álláspontot képviselö bíróságok elutasították a csekély mértékü sérelemdíj iránti kereseti követeléseket, azzal az indokolással, hogy a felperesek nem szenvedtek olyan mértékü sérelmet, ami alapot adhatna a sérelemdíj megítélésre. Ez utóbbi álláspontot tartotta Lábady is elfogadhatónak, az egyébként ismert indokokat kiegészítve azzal, hogy egy ellentétes gyakorlat, „,.. az ilyen itélkezés magának az intézménynek a rangját, komolyságát és méltóságát devalválná". (Lábady, 2016, 43.). Az ítélőtáblák döntéseinek eddigi vizsgálata alapján Tajti Judit is azt mutatta ki, hogy a joggyakorlat hajlik a bagatell igények elutasítására (Tajti, 2016, 32.). Míg az Alkotmánybíróság 1992. évi határozata a kisebb jogsértések esetén is érvényesíthető jogvédelem irányába tágította a nem vagyoni kártérítés szabályait, addig az új Ptk. normaszövegének értelmezése kapcsán inkább a sérelemdíjra való jogosultság szükítése melletti érvek kerültek túlsúlyba, amelynek a bírósági gyakorlatban történő elfogadása is körvonalazódik. Utalni szeretnék azonban arra, hogy az úgynevezett élvezeti árazás közgazdasági megközelítése alapján a bagatell igények kiszürése nem feltétlenül tartható (Szalai, 2017, 4.).

\section{Felhasznált irodalom}

Baranyai J. (1978): A polgári törvénykönyv módositásáról. Jogtudományi Közlöny, 9, 517-525.

Barzó T. (2017): A sérelemdij alkalmazásának új dimenziói az egészségügyi kártéritési perekben. Publicationes Universitatis Miskolcinensis Sectio Juridica et Politica, Tomus 35, 202-220.

Barzó T. - Sápi E. (2016): A sérelemdíj alkalmazhatósága a szerzői jogban. Miskolci Jogi Szemle, 2, 55-74.

Bónis G. (1980): A nem vagyoni kár a magyar jogban. In: Asztalos L. - Gönczöl K. (szerk.):

Felelősség és szankció a jogban. Budapest: Közgazdasági és Jogi Könyvkiadó, 339-357.

Boytha Gy. (2003): A személyiségi jogok megsértésének vagyoni szankcionálása. Polgári Jogi Kodifikáció, 1, 3-5.

Boytha Gy. (2008): A gyülöletbeszéd polgári jogi szankcionálásának alapjogi keretei. Polgári Jogi Kodifikáció, 1, 10-20.

Eörsi Gy. (1972): A szerződésen kivüli felelösség és a Ptk. reformja. Jogtudományi Közlöny, $3,65-75$.

Fejes E. (2017): A rendvédelmi testületek hivatásos állományába tartozó személyek képmáshoz füződő jogának korlátozhatósága. In: Görög M. - Menyhárd A. - Koltay A. (szerk.): A sze- 
mélyiség és védelme. Az Alaptörvény VI. cikkelyének érvényesülése a magyar jogrendszeren belül. Budapest: Eötvös Lóránd Tudományegyetem, Állam- és Jogtudományi Kar, 143-161.

Fézer T. (2011): A nem vagyoni (erkölcsi) sérelmek megitélése a polgári jogban. Budapest: HVG-ORAC Kiadó

Fézer T. (2014): Második Könyv. In: Osztovits A. (szerk.): A Polgári Törvénykönyvröl szóló 2013. évi V. törvény és a kapcsolódó jogszabályok nagykommentárja I-IV. Budapest: Opten Kiadó, 339.

Fézer T. (2018): Az erkölcsi károk megtéritése, de lege lata és de lege ferenda. Doktori (PhD) értekezés. Miskolc, Miskolci Egyetem Állam- és Jogtudományi Kar

Fuglinszky Á. (2015): Kártéritési jog. Budapest: HVG-ORAC Kiadó

Görög M. (2004): A nem vagyoni kártérités kiterjesztése az általános személyiségi jog megsértésének eseteire. Acta Universitatis Szegediensis: Acta Juridica et Politica, 7, 1-33.

Görög M. (2010): A személyhez füzödő jogok védelmét deklaráló generálklauzula. In: Csöndes M. - Nemessányi Z. (szerk.): Merre tart a magyar civilisztikai jogalkotás a XXI. század elején? Pécs: Kódex Kiadó, 125.

Görög M. (2014): Gondolatok a személyiségi jogsérelem csekély volta esetén érvényesitendö sérelemdij iránti igényről. Acta Universitatis Szegediensis: Acta Juridica et Politica, 76, 159-168.

Kárpáti J. - Kóczián S. (2014): Személyiségi jogok védelme az új polgári törvénykönyvben. In: Bodrogi B. - Kárpáti J. (szerk.): Személyiségi jogok és sajtószabadság. Budapest: Szerzői kiadás Koltay A. (2015): A jóhirnév és a becsület védelme a közügyek szabad vitáinak és a közéleti szereplök jogainak fényében. In: Koltay A.- Nyakas L. (szerk.): Magyar és európai médiajog. Budapest: Wolters Kluwer, 309-347.

Lábady T. (2016): Sérelemdij versus nem vagyoni kár. Állam- és Jogtudomány, 1, 40-45.

Landi B. (2014): A személyiségsértés szankciórendszerének sajátosságai a polgári jog rendszerében - történeti visszatekintéssel. Jogtudományi Közlöny, 2, 93-104.

Lenkovics B. (2009): A magánjog ember- és társadalomképe. In: Kisfaludi A. (szerk.): Liber amicorum. Studia L. Vékás Dedicata. Ünnepi dolgozatok Vékás Lajos tiszteletére. Budapest: ELTE Polgári Jogi Tanszék, 203-214.

Nagy G. (2014): Sérelemdij, mi változik? In: Fazekas Marianna (szerk.): Jogi Tanulmányok. Budapest: ELTE ÁJK Doktori Iskola, 587-597.

Papp J. T. (2017): A rendörök képmáshoz való jogának kérdése. In: Görög M. - Menyhárd A. - Koltay A. (szerk.): A személyiség és védelme. Az Alaptörvény VI. cikkelyének érvényesülése a magyar jogrendszeren belül. Budapest: Eötvös Lóránd Tudományegyetem, Állam- és Jogtudományi Kar, 119-142.

Pataki J. I. (2017): A birósági végrehajtás és a sérelemdíj. Polgári Szemle, 4-6, 318-328.

Petrik F. (2001): A személyiség jogi védelme. A sajtó-helyreigazitás. Budapest: HVG-ORAC Lap- és Könyvkiadó

Petrik F. (2003): A nem vagyoni kár megtéritése védelmében. Polgári Jogi Kodifikáció, 1, 6. Petrik F. (2013): Ptk. Második Könyv Harmadik és Negyedik rész. In: Wellmann Gy. (szerk.): 
Az új Ptk. magyarázata I/VI. Budapest: HVG-ORAC Kiadó, 172-236.

Pribula L. (2016): A sérelemdij, mint a nem vagyoni kártérités ,jogutódja”? - A jogintézmény bevezetésének eljárásjogi problémái. Jogtudományi Közlöny, 3, 129-138.

Sándor I. (2018): Az 1959. évi IV. törvény megalkotása és módositásai 1989-ig. In: Sárközy T. (szerk.): Tanulmánykötet az 1959-es Polgári Törvénykönyv elökészítéséről, alapvető intézményeiről és fejlődésmenetéről I-II. Budapest: Magyar Közlöny Lap- és Könyvkiadó, 9-235.

Sipka P.-Zaccaria M. L. (2014): A sérelemdij megjelenésének lehetséges hatásai a munkaügyi itélkezésre. In: Szalma J. (szerk.): A Magyar Tudomány Napja a Délvidéken 2013. Újvidék: Vajdasági Magyar Tudományos Társaság, 321-339.

Szabó I. (2008): A személyiségi jogok védelmi rendszere a magyar jogban. Acta Conventus de Iure Civili, 2.

Szalai Á. (2017): Nem-vagyoni kár, sérelemdij és joggazdaságtan. Pázmány Law Working Papers, 8.

Szalma J. (2018): Sérelemdij és a személyiségi jogok megsértésének magánjogi szankciói az európai és a magyar jogban. Acta Caroliensia Conventorum Scientiorum Iuridico-Politicarum XXI. Budapest: Károli Gáspár Református Egyetem, Állam- és Jogtudományi Kar

Székely L. (2008): Második Könyv I. rész, III. rész. In: Vékás L. (szerk.): Szakértői Javaslat az új Polgári Törvénykönyv tervezetéhez. Budapest: Complex Kiadó

Székely L. (2011): A személyiségi jogok hazai elmélete. A forrásvidék. Budapest: Eötvös Kiadó

Székely L. (2014): Második Könyv Elsö-Második rész, Harmadik rész. In: Vékás L.- Gárdos P. (szerk.). Kommentár a Polgári Törvénykönyvhöz I-II. Budapest: Wolters Kluwer

Tajti J. (2016): A sérelemdij és alakuló birói gyakorlata. Jogi Fórum, november. https://www. jogiforum.hu/files/publikaciok/tajti_judit_serelemdij_es_az_alakulo_biroi_gyakorlata\%5bjogi_forum $\% 5$ d.pdf

Tattay L. (2006): Közszereplők rágalmazási ügyei. Belügyi Szemle, 6, 35-57.

Tattay L. (2008): A közszereplök képmásának védelme. Acta Conventus de Iure Civili, 2.

Törő K. (1972): Polgári jogunk szabályozási rendszerének néhány elméleti és gyakorlati kérdése. Jogtudományi Közlöny, 11, 545-558.

Vékás L. (2005): Sérelemdij-fájdalomdij: Gondolatok az új Ptk. reformjavaslatáról. Magyar Jog, 4, 193-207.

Világhy M. (1968): Áruviszony és polgári jog. Állam- és Jogtudomány, 3, 445-473.

Zoltán Ö. (1961): Felelősség szerződésen kivül okozott károkért. Budapest: Közgazdasági és Jogi Könyvkiadó

\section{Jogszabályi hivatkozások}

1/2012. számú BKMPJE határozat.

1/2015. számú BKMPJE határozat. 
16/2016. (X. 20.) AB határozat.

1914. évi XIV. törvénycikk.

1959. IV. Törvény a Magyar Köztársaság Polgári Törvénykönyvéröl.

2012. évi C. törvény a Büntető Törvénykönyvröl.

2013. évi V. törvény a Polgári Törvénykönyvröl.

28/2014. (IX. 29.) AB határozat.

3/2017. (II. 21) AB határozat.

34/1992 (VI. 1.) AB határozat.

8/1990. (IV. 23.) AB határozat.

A Fővárosi Ítélőtábla Polgári Kollégiuma 1/2013. (VI. 17.) számú határozatával elfogadott kollégiumi véleménye a nem vagyoni kártérítés/sérelemdíj megtérítése iránti követelések elbírálásának a polgári perben felmerülő egyes kérdéseiröl.

BDT 1999/4.

BDT 2003/823.

BDT 2004/932.

BDT 2006/1298.

BDT 2007/1663.

BDT 2007/1682.

BDT 2008/1899.

BDT 2009/1962.

BDT 2009/2126.

BDT 2012/2609.

BDT 2012/2780.

BDT 2014/3076.

BH 1976/492.

BH 1985/17.

BH 1985/57.

BH 1992/455.

BH 1995/632.

BH 1997/276.

BH 1997/6.

BH 2000/485.

BH 2002/178.

BH 2002/7.

BH 2004/180.

BH 2006/282.

BH 2008/181.

BH 2008/266.

EBH 2000/296. 
EBH 2001/519.

EBH 2012./P.16.

Emberi Jogok Európai Egyezménye.

IV/2950-14/2015. számú AB határozat.

Magyarország Alaptörvénye.

Magyarország Kormánya T/7971. számú törvényjavaslat a Polgári Törvénykönyvről (miniszteri indokolás).

Polgári és Politikai jogok Nemzetközi Egyezségokmánya. 